Article

\title{
Assessment of the Antimicrobial and Antiproliferative Activities of Chloropyrazine-Tethered Pyrimidine Derivatives: In Vitro, Molecular Docking, and In-Silico Drug-Likeness Studies
}

\author{
Richie R. Bhandare ${ }^{1,2, *}$ and Afzal Basha Shaik ${ }^{3, *}$ (D) \\ 1 Department of Pharmaceutical Sciences, College of Pharmacy \& Health Sciences, Ajman University, \\ Ajman P.O. Box 340, United Arab Emirates \\ 2 Center of Medical and Bio-allied Health Sciences Research, Ajman University, \\ Ajman P.O. Box 340, United Arab Emirates \\ 3 Department of Pharmaceutical Chemistry, Vignan Pharmacy College, Vadlamudi 522213, India \\ * Correspondence: r.bhandareh@ajman.ac.ae (R.R.B.); bashafoye@gmail.com (A.B.S.); \\ Tel.: +97-15-6564-6655 (R.R.B.); +91-99-6601-4374 (A.B.S.)
}

check for updates

Citation: Bhandare, R.R.; Shaik, A.B. Assessment of the Antimicrobial and Antiproliferative Activities of Chloropyrazine-Tethered Pyrimidine Derivatives: In Vitro, Molecular Docking, and In-Silico Drug-Likeness Studies. Appl. Sci. 2021, 11, 10734. https://doi.org/10.3390/app 112210734

Academic Editor: Greta Varchi

Received: 1 October 2021

Accepted: 8 November 2021

Published: 14 November 2021

Publisher's Note: MDPI stays neutral with regard to jurisdictional claims in published maps and institutional affiliations.

Copyright: (c) 2021 by the authors. Licensee MDPI, Basel, Switzerland. This article is an open access article distributed under the terms and conditions of the Creative Commons Attribution (CC BY) license (https:/ / creativecommons.org/licenses/by/ $4.0 /)$.

\begin{abstract}
Molecular hybridization $(\mathrm{MH})$ of heterocyclic rings has enabled scientists to design and develop novel drugs and drug-like candidates. In our previous work, considering the importance of $\mathrm{MH}$, we synthesized different kinds of chloropyrazine-tethered pyrimidine derivatives (22-40) containing either substituted phenyl or heteroaryl rings at position- 6 of the pyrimidine ring and evaluated their antitubercular activity. Herein, we report the antimicrobial and antiproliferative activities of 22-40. The antiproliferative activity of the target hybrids was superior to the antimicrobial activity. However, some compounds showed greater antimicrobial activity than the standard drugs. For instance, among the nineteen derivatives, compound 31 containing a $2^{\prime \prime}, 4^{\prime \prime}$-dichlorophenyl ring, showed the most potent antibacterial and antifungal activities (MIC $45.37 \mu \mathrm{M}$ ), followed by compounds 25 and 30 bearing $4^{\prime \prime}$-nitrophenyl and $2^{\prime \prime}, 4^{\prime \prime}$-difluorophenyl scaffolds with minimum inhibitory concentrations (MIC) values of $48.67 \mu \mathrm{M}$ and $50.04 \mu \mathrm{M}$, respectively. Compound 35, containing a bioisosteric $2^{\prime \prime}$-pyridinyl ring, showed the most potent antiproliferative activity against the prostate cancer cell line (DU-145) with an $\mathrm{IC}_{50}$ value of $5 \pm 1 \mu \mathrm{g} / \mathrm{mL}$. Additional testing of compounds 22-40 on human normal liver cells (LO2) indicated that the compounds were more selective to cancer cell lines over normal cells. Further, molecular docking of the most potent compound 35 against dihydrofolate reductase (DHFR) (PDB ID: 1U72) had a good binding affinity with a docking score of -6.834 . The SwissADME program estimated the drug-likeness properties of compound 35 . Hybrid 35 is a potential lead molecule for the development of new anticancer drugs, whereas 31 is a promising antimicrobial lead candidate.
\end{abstract}

Keywords: molecular hybridization; heterocyclic rings; chloropyrazine; pyrimidine; antiproliferative activity; antimicrobial activity; cytotoxicity; molecular docking; drug-likeness

\section{Introduction}

Heterocyclic scaffolds are interesting chemical structures that are vital in the discovery of novel drugs for the diagnosis and treatment of diseases. Generally, medicinal chemists tether bioactive heterocyclic motifs in order to produce better drugs. Generally, medicinal chemists explore the strategy of combining the entire molecule or a part of the structure such as two or more heterocyclic rings, which can lead to the generation of new types of structures that have potential bioactivities, and this approach is called molecular hybridization (MH). The design, synthesis, and screening of different heterocyclic hybrids are interesting due to their excellent pharmacological properties and ease of preparation. Many heterocyclic rings are privileged structures due to their significant biological profiles. 
Hybridization can provide these qualities that can further make the drugs with heterocyclic moieties to have better profiles in terms of their pharmacokinetics, pharmacodynamics, and toxicities [1]. The MH approach not only enhances the pharmacological activity of newly prepared compounds but also modulates the pharmacokinetic properties associated with each heterocyclic scaffold [2]. Additionally, heterocyclic hybrids have good interactions with the molecular drug target and they may have a dual or entirely new mode of action [3]. Nine of the 12 drugs approved in 2021 by the US FDA contain one or more privileged heterocyclic rings as their core elements that are crucial for their activity [4]. This state indicates the implication of utilizing heterocyclic scaffolds in drug discovery programs through the MH strategy.

Pyrazine and pyrimidine are important six-membered nitrogenous rings belonging to a class of heterocyclic compounds known as diazines that are commonly distributed in many pharmacologically useful compounds. These rings are present as the fundamental pharmacophoric group in a variety of drug molecules that are used to treat different diseases. The pyrazine scaffold is present in antitubercular drugs, i.e., pyrazinamide and morinamide; bortezomib, an anti-cancer agent used in multiple myeloma; potassium channel blocker antidiabetic-glipizide; antihyperlipidemic triglyceride lipase inhibitor acipimox; and the potassium sparing diuretics, i.e., amiloride and benzamil [5]. On the other hand, pyrimidine is one of the routinely seen scaffold in drug molecules. This ring is particularly found in drugs used as chemotherapeutic agents because of its ability to interfere with the central metabolic pathways including folate and nucleic acid synthesis. Examples of drugs with a pyrimidine nucleus are antibacterial and antimalarial agents targeting the folate pathway: trimethoprim, iclaprim, sulfadimethoxine, pyrimethamine, and sulfadoxine; antimetabolite and ergosterol biosynthesis inhibitor antifungal drugs: flucytosine and voriconazole; antimetabolite anti-cancer agents: 5-fluorouracil and capecitabine; tyrosine kinase inhibitors: imatinib, dasatinib, and nilotinib; antivirals: ara-c, idoxuridine, zidovudine, stavudine, lamivudine, and emtricitabine; and the antitubercular drug capreomycin (Figure 1). Many substituted pyrazine derivatives were reported with potential antibacterial [6-11], antifungal [12-15], anticancer [16-21], antioxidant [22-25], and antitubercular $[9,26-28]$ activities. Similarly, pyrimidine-based compounds also showed excellent antimicrobial (antibacterial and antifungal) [29-33], antimycobacterial [34-38], antioxidant [39-42], cytotoxic and anticancer [42-52], and antiviral [51-53] properties.<smiles>CC(C)C[C@H](NC(=O)[C@H](Cc1ccccc1)NC(=O)c1cnccn1)B(O)O</smiles>
(Anticancer)<smiles>COc1cc(Cc2cnc(N)nc2N)cc(OC)c1OC</smiles>

Trimethoprim (Antibacterial)

$$
\begin{aligned}
& \text { Pyrazinamide } \\
& \text { (Antitubercular) }
\end{aligned}
$$<smiles>NC(=O)c1nc(F)cnc1O</smiles>

Favipiravir (Antiviral)<smiles>Cc1cc(NC(=O)c2ccc(C)c(Nc3nccc(-c4cccnc4)n3)c2)cc(-n2cnc(C)c2)c1</smiles><smiles>CCc1nc(N)nc(N)c1-c1ccc(Cl)cc1</smiles><smiles>[Y19]C1CC(n2cc(C)c(=O)[nH]c2=O)COC1CO</smiles>

Figure 1. Chemical structures of selected drugs comprising pyrazine and pyrimidine scaffolds. 
In our previous study, we reported the antimicrobial and antiproliferative activities of chloropyrazine-linked 1,5-benzothiazepine hybrids [54]. Considering the significant biological activities of pyrimidine derivatives, previously we synthesized and evaluated the antitubercular activity of chloropyrazine-tethered pyrimidine hybrids (22-40) [55]. These derivatives (22-40) are analogues of chloropyrazine-linked 1,5-benzothiazepine hybrids where the pyrimidine ring replaces the 1,5-benzothiazepine motif with the other parts of the compounds being the same (Figure 2). Here, we report the antimicrobial as well as the antiproliferative activities of chloropyrazine-tethered pyrimidine hybrids with the aim to develop potent antimicrobial and antiproliferative hybrids.

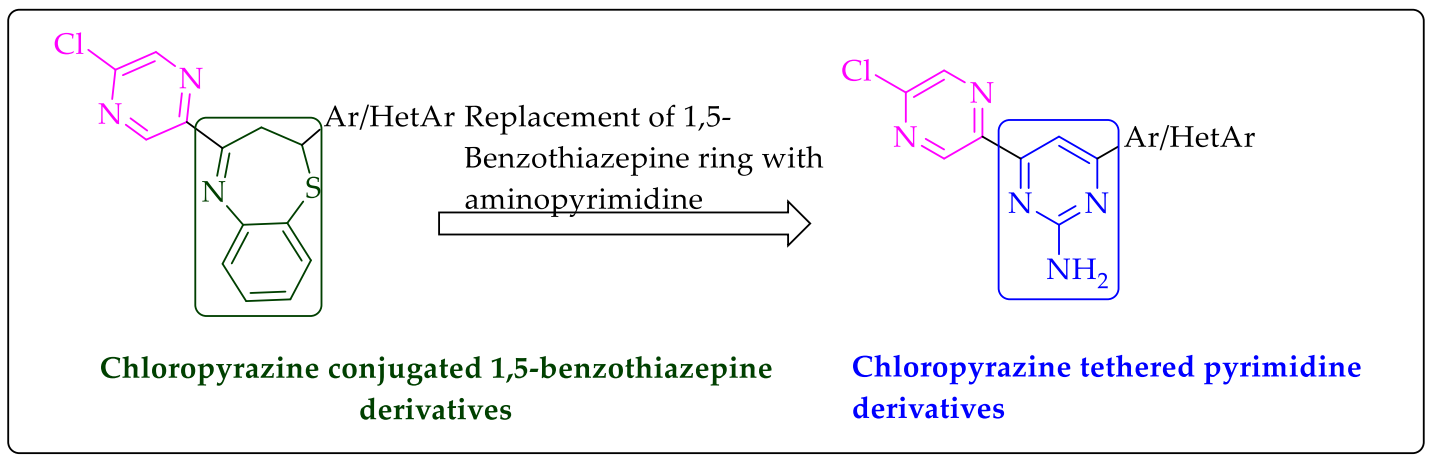

Figure 2. Design of chloropyrazine-tethered pyrimidine derivatives.

\section{Results \& Discussion}

\subsection{Chemistry}

The different chloropyrazine-tethered pyrimidine derivatives (22-40) were obtained by the condensation of chloropyrazinyl chalcones (1-19) with guanidine hydrochloride (Scheme 1) using a base catalyst $(\mathrm{KOH})$ in yields ranging from $56-92 \%$. The molecular structures of the chloropyrazine-tethered pyrimidine hybrids were disentangled using FT-IR and ${ }^{1} \mathrm{H}$ NMR spectral data and are presented in our previous paper [55].<smiles>[R]C=CC(=O)c1cnc(Cl)cn1</smiles>
$1-19$

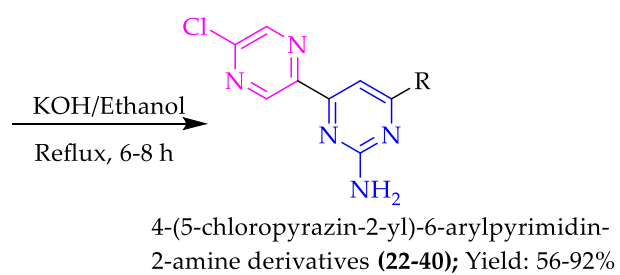

Disubstituted phenyl derivatives

9, 30: $\mathrm{R}=2$ ", 4"-difluorophenyl

10, 31: $\mathrm{R}=2 ", 4$ "-dichlorophenyl

11, 32: $\mathrm{R}=3$ ", 4 "-dimethoxyphenyl;

12, 33: $\mathrm{R}=3$ "-methoxy-4"-hydroxyphenyl

Trisubstituted phenyl derivatives

13, 34: R = 3",4",5"--trimethoxyphenyl 


\subsection{Biological Studies}

\subsubsection{Antibacterial Activity}

Compounds 22-40 were tested for antibacterial activity against four bacterial strains, namely, B. subtilis, S. aureus, E. coli, and P. aeruginosa, using ciprofloxacin as a standard drug, and the results are summarized in Table 1. The physicochemical properties of the chloropyrazine-tethered pyrimidine derivatives were modulated by incorporation of phenyl ring-bearing electron withdrawal and electron-donating groups along with bioisosteric heteroaryl substitution of the phenyl ring at the 6th position of the pyrimidine scaffold.

Table 1. Antibacterial activity of chloropyrazine-tethered pyrimidine hybrids (22-40) (MIC in $\mu \mathrm{M})$.

\begin{tabular}{|c|c|c|c|c|c|}
\hline Compound No. & $\mathbf{R}$ & $\begin{array}{c}\text { B. subtilis } \\
(\mathrm{MIC}=\mu \mathrm{M})\end{array}$ & $\begin{array}{c}\text { S. aureus } \\
(\mathrm{MIC}=\mu \mathrm{M})\end{array}$ & $\begin{array}{c}\text { E. coli } \\
(\mathrm{MIC} \text { in } \mu \mathrm{M})\end{array}$ & $\begin{array}{l}\text { P. aeruginosa } \\
(\mathrm{MIC} \text { in } \mu \mathrm{M})\end{array}$ \\
\hline 22 & Phenyl & $>200 \pm 0.92$ & $>200 \pm 0.88$ & $>200 \pm 0.53$ & $>200 \pm 0.43$ \\
\hline 23 & $4^{\prime \prime}$-chlorophenyl & $50.28 \pm 0.09$ & $50.28 \pm 0.28$ & $50.28 \pm 0.19$ & $50.28 \pm 0.89$ \\
\hline 24 & $4^{\prime \prime}$-fluorophenyl & $53.03 \pm 0.38$ & $53.03 \pm 0.56$ & $53.03 \pm 0.28$ & $53.03 \pm 0.62$ \\
\hline 25 & $4^{\prime \prime}$-nitrophenyl & $48.67 \pm 0.66$ & $48.67 \pm 0.43$ & $48.67 \pm 0.22$ & $48.67 \pm 0.42$ \\
\hline 26 & $4^{\prime \prime}$-hydroxyphenyl & $>200 \pm 0.58$ & $>200 \pm 0.15$ & $>200 \pm 0.19$ & $>200 \pm 0.22$ \\
\hline 27 & $4^{\prime \prime}$-methylphenyl & $>200 \pm 0.23$ & $>200 \pm 0.62$ & $>200 \pm 0.38$ & $>200 \pm 0.73$ \\
\hline 28 & $4^{\prime \prime}$-methoxyphenyl & $>200 \pm 091$ & $>200 \pm 0.45$ & $>200 \pm 0.38$ & $>200 \pm 0.56$ \\
\hline 29 & $4^{\prime \prime}$-dimethylaminophenyl & $195.84 \pm 0.16$ & $>200 \pm 0.92$ & $>200 \pm 0.55$ & $>200 \pm 0.75$ \\
\hline 30 & $2^{\prime \prime}, 4^{\prime \prime}$-difluorophenyl & $50.04 \pm 0.31$ & $50.04 \pm 0.21$ & $50.04 \pm 0.81$ & $\mathbf{5 0 . 0 4} \pm 0.88$ \\
\hline 31 & $2^{\prime \prime}, 4^{\prime \prime}$-dichlorophenyl & $45.37 \pm 0.63$ & $45.37 \pm 0.33$ & $45.37 \pm 0.29$ & $45.37 \pm 0.54$ \\
\hline 32 & $3^{\prime \prime}, 4^{\prime \prime}$-dimethoxyphenyl & $>200 \pm 0.47$ & $>200 \pm 0.82$ & $>200 \pm 0.94$ & $>200 \pm 0.18$ \\
\hline 33 & $3^{\prime \prime}$-methoxy-4" -hydroxyphenyl & $>200 \pm 0.52$ & $>200 \pm 0.71$ & $>200 \pm 0.79$ & $>200 \pm 0.95$ \\
\hline 34 & $3^{\prime \prime}, 4^{\prime \prime}, 5^{\prime \prime}$-trimethoxyphenyl & $85.60 \pm 0.28$ & $85.60 \pm 0.66$ & $85.60 \pm 0.56$ & $85.60 \pm 0.56$ \\
\hline 35 & $2^{\prime \prime}$-pyridinyl & $>200 \pm 0.62$ & $>200 \pm 0.59$ & $>200 \pm 0.22$ & $>200 \pm 0.28$ \\
\hline 36 & $3^{\prime \prime}$-pyridinyl & $>200 \pm 0.93$ & $>200 \pm 0.83$ & $>200 \pm 0.38$ & $>200 \pm 0.33$ \\
\hline 37 & $4^{\prime \prime}$-pyridinyl & $>200 \pm 0.99$ & $>200 \pm 0.77$ & $>200 \pm 0.76$ & $>200 \pm 0.39$ \\
\hline 38 & $2^{\prime \prime}$-thienyl & $>200 \pm 0.91$ & $>200 \pm 0.32$ & $>200 \pm 0.43$ & $>200 \pm 0.53$ \\
\hline 39 & $2^{\prime \prime}$-furfuryl & $>200 \pm 0.82$ & $>200 \pm 0.41$ & $>200 \pm 0.24$ & $>200 \pm 0.77$ \\
\hline 40 & $5^{\prime \prime}$-pyrrolyl & $>200 \pm 0.65$ & $>200 \pm 0.59$ & $>200 \pm 0.61$ & $>200 \pm 0.82$ \\
\hline Ciprofloxacin & & $145.71 \pm 0.18$ & $145.71 \pm 0.18$ & $72.85 \pm 0.33$ & $72.85 \pm 0.33$ \\
\hline
\end{tabular}

The numbers in bold designate the activity of the compounds with more potency than the reference standard.

Nonsubstitution on the phenyl ring resulted in abolishment of the activity $(22=\mathrm{MIC}$ $>200 \mu \mathrm{M}$ ). Among the monosubstituted phenyl-based pyrimidine derivatives (23-29) containing different kinds of electron release and electron withdrawal groups at position$4^{\prime \prime}$, the activity ranged from 48.67-200 $\mu \mathrm{M}$. The compounds with electron withdrawal groups at position- $4^{\prime \prime}$ of the phenyl ring (23-25) exhibited activity with MIC in the range of 48.67-53.03 $\mu \mathrm{M}$. These compounds were more potent than the reference drug ciprofloxacin $(\mathrm{MIC}=145.71 \mu \mathrm{M})$. Among these three, the analogue 25 bearing a $4^{\prime \prime}$-nitro group was most active with an MIC of $48.6 \mu \mathrm{M}$. Replacement of the nitro group at the para position by chlorine and fluorine atoms in compounds $\mathbf{2 3}$ and $\mathbf{2 4}$ decreased the antibacterial activity compared with 25 . On the other hand, the presence of electron-donating groups in position$4^{\prime \prime}$ of the phenyl ring (26-29) appeared to be detrimental for antibacterial activity.

The derivatives with disubstitution on the phenyl ring at $2^{\prime \prime}, 4^{\prime \prime}$-positions showed good activity. Among them, the best activity was displayed by compound 31 with $2^{\prime \prime}, 4^{\prime \prime}$ dichlorophenyl substitution with an MIC of $45.37 \mu \mathrm{M}$. This derivative was the most active among all the compounds, with 3-fold more potency than the standard. Replacement of 
$2^{\prime \prime}, 4^{\prime \prime}$-di-Cl by $2^{\prime \prime}, 4^{\prime \prime}$-di-F (30) reduced the activity. Incorporation of the electron-donating groups at the meta and para positions was found to be deleterious $(32 \& 33, \mathrm{MIC}=>200 \mu \mathrm{M})$ as there was a negative effect on the antibacterial activity. While $3^{\prime \prime}, 4^{\prime \prime}$-dimethoxyphenyl derivative 32 was inactive, introduction of a third methoxy group led to compound $\mathbf{3 4}$ with enhanced activity (MIC of $85.60 \mu \mathrm{M}$ ). The presence of heterocyclic substituents, independent of their position as well as nonsubstitution was detrimental (Figures 3 and 4). Among the bioisosteres (35-40), the activity was found to be $>200 \mu \mathrm{M}$. Irrespective of the incorporation of various heterocycles, the activity was not found to be improved over standard ciprofloxacin. Overall, the most potent compound 31 was 3.2-times more potent against Gram-positive organisms and 1.6-fold more active against Gram-negative bacterial strains than Gram-positive strains. Thus, it can be concluded that activity of these group of compounds depends not only on the nature and position of the substituent on the phenyl ring but also on the number of substituents.

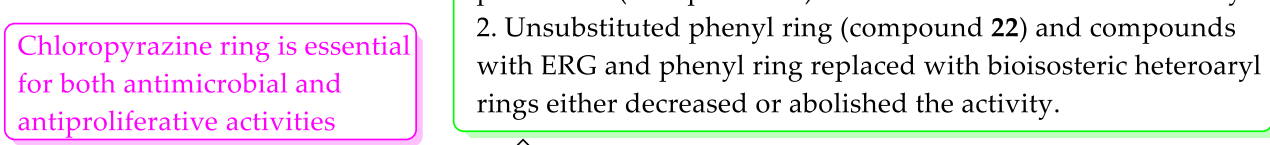

Figure 3. Structure-activity relationship (SAR) features of chloropyrazine-tethered pyrimidine hybrids. EWD $=$ Electron withdrawal; ERG: Electron-releasing group.

\subsubsection{Antifungal Activity}

The target hybrids were screened for antifungal activity against the fungal strains A. niger and C. tropicalis using Fluconazole as a positive control (Table 2). Among the monosubstituted derivatives with substituents at the $4^{\prime \prime}$-position of the phenyl ring, the MICs ranged from 97.34 to $214.94 \mu \mathrm{M}$ and among them, good activity was exhibited by nitro derivative (25) with an MIC of $97.34 \mu \mathrm{M}$. In general, within the monosubstituted derivatives, compounds bearing electron-withdrawing substituents $\left(\mathrm{F}, \mathrm{Cl}, \& \mathrm{NO}_{2}\right)$ showed 2-4-fold better activity over compounds containing electron-releasing groups such as hydroxy $(\mathrm{OH})$, methoxy $\left(\mathrm{OCH}_{3}\right)$, methyl $\left(\mathrm{CH}_{3}\right)$, and dimethyl amino $\left(\mathrm{N}\left(\mathrm{CH}_{3}\right)_{2}\right.$. The order of activity of the monosubstituted derivatives was $4^{\prime \prime}-\mathrm{NO}_{2}>4^{\prime \prime}-\mathrm{Cl}>4^{\prime \prime}-\mathrm{F}>4^{\prime \prime}-\mathrm{N}\left(\mathrm{CH}_{3}\right)_{2}>>$ $4^{\prime \prime}-\mathrm{OH}=4^{\prime \prime}-\mathrm{Me}-4^{\prime \prime}-\mathrm{OMe}$. 


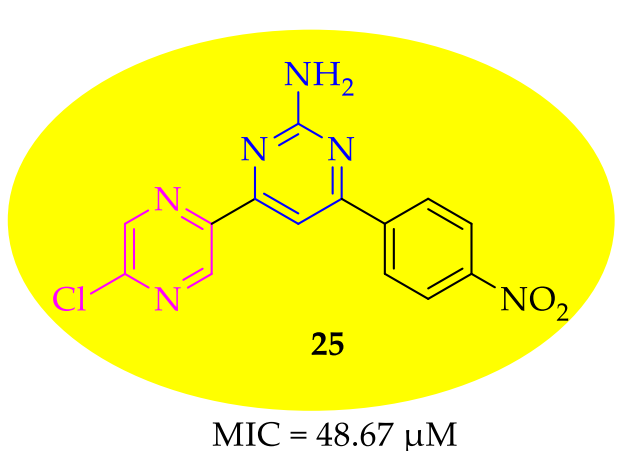

Potent Antibacterial activity

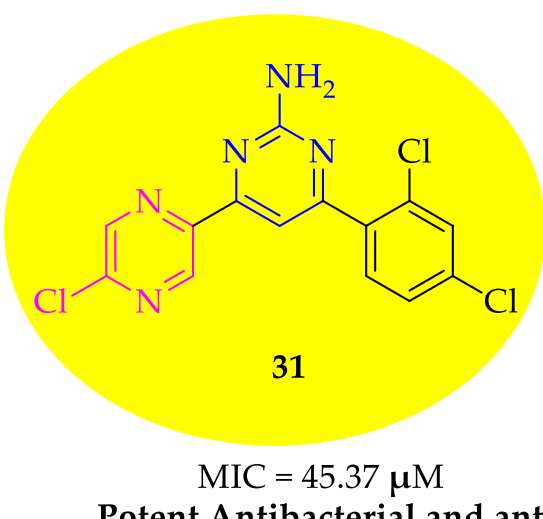

Potent Antibacterial and antifungal activities

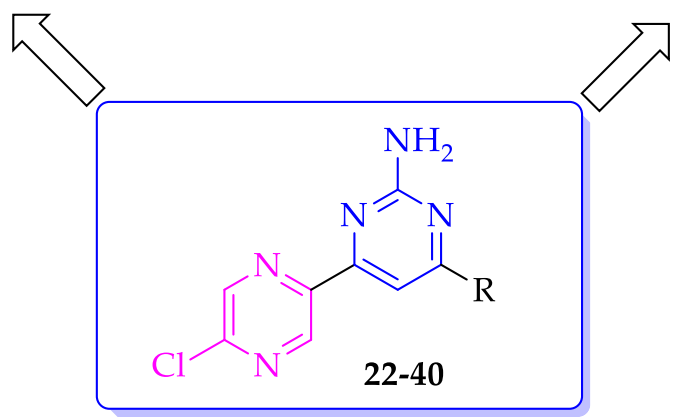

Potential antiproliferative compound

Figure 4. Structures of the most potent chloropyrazine-tethered pyrimidine hybrids.

Among the disubstituted compounds, when the phenyl ring was substituted with $\mathrm{F}$ $(30, \mathrm{MIC}=50.04 \mu \mathrm{M})$ or $\mathrm{Cl}(31, \mathrm{MIC}=45.37 \mu \mathrm{M})$ at the ortho and para positions of the phenyl ring, the activity was improved by twofold over compounds $23(\mathrm{MIC}=100.57 \mu \mathrm{M}) \&$ $24(\mathrm{MIC}=106.06 \mu \mathrm{M})$. Interestingly, compound 32, containing $3^{\prime \prime}, 4^{\prime \prime}$-dimethoxysubstitution, had fourfold ( $\mathrm{MIC}=46.52 \mu \mathrm{M}$ ) higher antifungal activity compared to its monosubstituted counter compound $28(\mathrm{MIC}=>200 \mu \mathrm{M})$ against $A$. niger. However, the activity of 32 was not favorable against $C$. tropicalis $(32, \mathrm{MIC}=186.17 \mu \mathrm{M})$. The best activity among all compounds tested was observed for the $2^{\prime \prime}, 4^{\prime \prime}$-di-Cl-substituted compound 31 with an MIC of $45.37 \mu \mathrm{M}$, followed by compound $32(\mathrm{MIC}=46.52 \mu \mathrm{M})$. Both compounds were found to be almost twice as potent as fluconazole against $A$. niger and around 1.4-times as potent against C.tropicalis. In this case, the order of activity was $2^{\prime \prime}, 4^{\prime \prime}-\mathrm{di}-\mathrm{Cl}>3^{\prime \prime}, 4^{\prime \prime}$-di-OMe $>$ $2^{\prime \prime}, 4^{\prime \prime}$-di-F $>3^{\prime \prime}$-OMe $>4^{\prime \prime}-\mathrm{OH}$. 
Table 2. Antifungal $(\mu \mathrm{M})$, antiproliferative and cytotoxic $(\mu \mathrm{g} / \mathrm{mL})$ activities of chloropyrazine-tethered pyrimidine hybrids (22-40).

\begin{tabular}{|c|c|c|c|c|c|}
\hline $\begin{array}{l}\text { Compound } \\
\text { No. }\end{array}$ & $\mathbf{R}$ & $\begin{array}{c}\text { A. niger } \\
(\mathrm{MIC}=\mu \mathrm{M} \pm \mathrm{SD})\end{array}$ & $\begin{array}{c}\text { C. tropicalis } \\
(\mathrm{MIC}=\mu \mathrm{M} \pm \mathrm{SD})\end{array}$ & $\begin{array}{c}{ }^{*} \mathrm{DU}-145 \\
\left(\mathrm{IC}_{50}=\mu \mathrm{g} / \mathrm{mL} \pm \mathrm{SD}\right)\end{array}$ & $\begin{array}{l}\text { * Human Normal Liver } \\
\text { Cells (L02; } \mu \mathrm{g} / \mathrm{mL})\end{array}$ \\
\hline 22 & Phenyl & $>200 \pm 0.91$ & $>200 \pm 0.58$ & $40 \pm 1$ & $>40$ \\
\hline 23 & $4^{\prime \prime}$-chlorophenyl & $100.57 \pm 0.52$ & $100.57 \pm 0.16$ & $18 \pm 2$ & $>40$ \\
\hline 24 & $4^{\prime \prime}$-fluorophenyl & $106.06 \pm 0.19$ & $106.06 \pm 0.88$ & $47 \pm 2$ & $>40$ \\
\hline 25 & $4^{\prime \prime}$-nitrophenyl & $97.34 \pm 0.28$ & $97.34 \pm 0.52$ & $112 \pm 2$ & $>40$ \\
\hline 26 & $4^{\prime \prime}$-hydroxyphenyl & $>200$ & $>200 \pm 0.66$ & $121 \pm 2$ & $>40$ \\
\hline 27 & $4^{\prime \prime}$-methylphenyl & $>200$ & $>200 \pm 0.73$ & $132 \pm 2$ & $>40$ \\
\hline 28 & $4^{\prime \prime}$-methoxyphenyl & $>200$ & $>200 \pm 0.22$ & $88 \pm 2$ & $>40$ \\
\hline 29 & $4^{\prime \prime}$-dimethylaminophenyl & $195.84 \pm 0.98$ & $>200 \pm 0.81$ & $24 \pm 2$ & $>40$ \\
\hline 30 & $2^{\prime \prime}, 4^{\prime \prime}$-difluorophenyl & $50.04 \pm 1$ & $50.04 \pm 0.22$ & $10 \pm 2$ & $>40$ \\
\hline 31 & $2^{\prime \prime}, 4^{\prime \prime}$-dichlorophenyl & $45.37 \pm 0.66$ & $45.37 \pm 0.18$ & $12 \pm 2$ & $>40$ \\
\hline 32 & $3^{\prime \prime}, 4^{\prime \prime}$-dimethoxyphenyl & $46.52 \pm 0.99$ & $186.17 \pm 0.63$ & $72 \pm 2$ & $>40$ \\
\hline 33 & $3^{\prime \prime}$-methoxy-4" $4^{\prime \prime}$ hydroxyphenyl & $>200 \pm 0.87$ & $>200 \pm 0.29$ & $110 \pm 1$ & $>40$ \\
\hline 34 & $3^{\prime \prime}, 4^{\prime \prime}, 5^{\prime \prime}$-trimethoxyphenyl & $85.60 \pm 0.55$ & $85.60 \pm 0.90$ & $56 \pm 2$ & $>40$ \\
\hline 35 & $2^{\prime \prime}$-pyridinyl & $112.39 \pm 0.77$ & $56.19 \pm 0.34$ & $5 \pm 1$ & $>40$ \\
\hline 36 & $3^{\prime \prime}$-pyridinyl & $112.39 \pm 0.23$ & $112.39 \pm 0.30$ & $78 \pm 2$ & $>40$ \\
\hline 37 & $4^{\prime \prime}$-pyridinyl & $>200 \pm 0.58$ & $112.39 \pm 0.61$ & $52 \pm 2$ & $>40$ \\
\hline 38 & $2^{\prime \prime}$-thienyl & $110.44 \pm 0.71$ & $110.44 \pm 0.38$ & $82 \pm 2$ & $>40$ \\
\hline 39 & $2^{\prime \prime}$-furfuryl & $116.92 \pm 0.82$ & $>200 \pm 0.72$ & $96 \pm 2$ & $>40$ \\
\hline 40 & $5^{\prime \prime}$-pyrrolyl & $>200 \pm 0.85$ & $>200 \pm 0.53$ & $105 \pm 1$ & $>40$ \\
\hline Fluconazole & - & $84.14 \pm 0.19$ & $63.10 \pm 0.44$ & - & - \\
\hline Methotrexate & - & - & - & $11 \pm 1$ & $>75$ \\
\hline
\end{tabular}

The numbers in bold designate the activity of the compounds with more potency. ${ }^{*}$ Data are the mean $\pm \mathrm{SD}(n=3)$; IC 50 in $\mu \mathrm{g} / \mathrm{mL}$. The target hybrids and the standard were dissolved in DMSO and diluted with culture medium containing DMSO (0.1\%). The control cells were treated with culture medium containing DMSO $(0.1 \%)$.

Derivatives with bioisosteric heterocyclic substituents showed moderate activity, with MIC in the range of 110.44-200 $\mu \mathrm{M}$. The order of activity of these compounds was $2^{\prime \prime}$-thienyl $>2^{\prime \prime}$-pyridinyl $=3^{\prime \prime}$-pyridinyl $>2^{\prime \prime}$-furfuryl $>4^{\prime \prime}$-pyridinyl $=5^{\prime \prime}$-pyrrolyl. The six-membered heterocycle-based compounds (35-37) fared better over the five-membered ring containing compounds (38-40), and the best activity was seen for compound $35(\mathrm{MIC}=56.19 \mu \mathrm{M})$ with MIC 1.2-fold higher than that of Fluconazole against $C$. tropicalis. None of them exceeded the activity of the reference drug. Thus, the structure-activity relationship study showed the same behavior for monosubstituted derivatives as in the case of antibacterial activity. In the case of disubstitution, the presence of $2^{\prime \prime}, 4^{\prime \prime}$-di $\mathrm{Cl}(31)$ was favorable for antifungal activity followed by $3^{\prime \prime}, 4^{\prime \prime}-\mathrm{OMe}$ (32). Introduction of $2^{\prime \prime} .4^{\prime \prime}$-di-F (30) slightly decreased the activity compared to 32 , while the presence of $3^{\prime \prime}-\mathrm{OMe}, 4^{\prime \prime}-\mathrm{OH}$ substitution (33) was detrimental. In the case of heterocyclic substitution, $2^{\prime \prime}$-thienyl was found to have a positive effect on antifungal activity, while $4^{\prime \prime}$-pyridinyl and $5^{\prime \prime}$-pyrrolyl had very negative influences on antifungal activity (Figure 4)

\subsubsection{Antiproliferative Activity}

Next, the target chloropyrazine-tethered pyrimidine hybrids (22-40) were screened for antiproliferative activity against prostate cancer cell lines (DU-145) and normal human liver cell lines (LO2) using methotrexate as a standard (Table 2). In the monosubstituted phenylbased pyrimidine series, the prostate cancer $\mathrm{IC}_{50}$ s ranged from $18 \pm 2$ to $132 \pm 2 \mu \mathrm{g} / \mathrm{mL}$. Compound 23, containing the electron-withdrawing $4^{\prime \prime}-\mathrm{Cl}$ group, played a key role in improving the activity, with an $\mathrm{IC}_{50}$ value of $18 \pm 2 \mu \mathrm{g} / \mathrm{mL}$. According to the structureactivity relationships for monosubstituted derivatives, the most favorable was $2^{\prime \prime}, 4^{\prime \prime}$-di-Cl substitution (23), replacement of which by electron donating $4^{\prime \prime}-\mathrm{N}\left(\mathrm{CH}_{3}\right)_{2}$ (29) slightly decreased the activity. Introduction of the $2^{\prime \prime}, 4^{\prime \prime}$-di-F substituent (24) decreased the activity more, while the presence of the $4^{\prime \prime}-\mathrm{NO}_{2}$ group lowered activity. Finally, the presence of $4^{\prime \prime}$-Me was detrimental (Figure 4 ). The order of the antiproliferative activity of these derivatives was $4^{\prime \prime}-\mathrm{Cl}>4^{\prime \prime}-\mathrm{N}\left(\mathrm{CH}_{3}\right)_{2}>4^{\prime \prime}-\mathrm{F}>4^{\prime \prime}-\mathrm{NO}_{2}>4^{\prime \prime}-\mathrm{OMe}>4^{\prime \prime}-\mathrm{OH}>4^{\prime \prime}-\mathrm{Me}$.

Among the disubstituted analogues, the best activity was observed with the $2^{\prime \prime}, 4^{\prime \prime}$-di-F substituent (30) followed by $2^{\prime \prime}, 4^{\prime \prime}$-di-Cl (31), which were almost equipotent as methotrexate. 
Neither disubstitution nor trisubstitution of the phenyl ring with electron-donating groups brought any significant change in activity. Among the compounds bearing bioisosteric scaffolds, the activity ranged from $5 \pm 1$ to $105 \pm 1 \mu \mathrm{g} / \mathrm{mL}$. The best activity was observed for compound 35, with an $\mathrm{IC}_{50}$ value of $5 \pm 1 \mu \mathrm{g} / \mathrm{mL}$, which was twofold more active than the standard drug, i.e., methotrexate $(11 \pm 1 \mu \mathrm{g} / \mathrm{mL})$. The order of activity of this group of derivatives was $2^{\prime \prime}$-pyridinyl $>4^{\prime \prime}$-pyridinyl $>3^{\prime \prime}$-pyridinyl $>2^{\prime \prime}$-thienyl $>22^{\prime \prime}$-furyl $>$ $5^{\prime \prime}$-pyrrolyl.

The cytotoxicity against normal human liver cell lines (LO2) of compounds $\mathbf{2 2 - 4 0}$ and methotrexate was found to be greater than $40 \mu \mathrm{g} / \mathrm{mL}$ and $75 \mu \mathrm{g} / \mathrm{mL}$ respectively, indicating less selectivity of compounds towards the normal human liver cells over the prostate cancer cell lines, indicating the safety of the target compounds.

Comparison of the antibacterial, antifungal, and antiproliferative activities between benzothiazepines and pyrimidine derivatives indicated that both benzothiazepines and pyrimidine derivatives showed comparable antibacterial activities; however, the antifungal activity was improved in benzothiazepines compared to pyrimidine derivatives (21, MIC $19.01 \mu \mathrm{M}$ vs. $31 \mathrm{MIC} 45.37 \mu \mathrm{M}$ ). On the other hand, the pyrimidine derivative 35 $\left(\mathrm{IC}_{50}=5 \pm 1 \mu \mathrm{g} / \mathrm{mL}\right)$ displayed excellent antiproliferative activity in the series. The benzothiazepines and chloropyrazine-tethered pyrimidine hybrids displayed excellent safety profiles against the $\mathrm{LO} 2$ cell line.

Overall, the replacement of the 1,5-benzothiazepine ring with the pyrimidine scaffold improved the antiproliferative activity and reduced the antimicrobial activity in comparison to the benzothiazepine series. The SAR features of the target compounds are displayed in Figure 3. A summary of the potential compounds from this study with significant antibacterial, antifungal, and antiproliferative activities among $\mathbf{2 2 - 4 0}$ is depicted in Figure 4 .

\subsection{In Silico Studies}

\subsubsection{Molecular Docking}

The scaffolds similar to the target compounds were reported earlier with respect to their potent anticancer activities [56]. This prompted us to perform a computational molecular docking study to understand the interaction between the most active antiproliferative compound 35 and dihydrofolate reductase (DHFR) by using the GLIDE docking module of Schrödinger suite 2014-3 [57]. The docking study was carried out on compound 35, where the structure of the complex of DHFR and methotrexate was selected as the docking model (PDB ID: 1U72) [58]. Table 3 depicts the results of docking along with the major interactions for compound 35 and methotrexate with DHFR. More detailed analysis of compound 35 with the DHFR receptor is presented in Figure 5. Compound 35 showed a two-hydrogen bond interaction with the active residues Glu30 and Thr56. The amino part of pyrimidin-2-amine of compound 35 acts as a hydrogen bond donor and established a H-bond interaction with the active site residue Thr56 ( $(\mathrm{d}=3.57 \AA)$, and the nitrogen atom of 5-chloropyrazin-2-yl group acts as a hydrogen bond acceptor and formed a $\mathrm{H}$-bond with the active residue Glu30 ( $\mathrm{d}=2.02 \AA)$. Further, the pyrimidin-2-amine group of 35 formed an arene-arene $(\pi-\pi)$ interaction with the Phe 34 residue. Additionally, several hydrophobic interactions were observed between compound 35 and the active site residues of DHFR i.e., Ile7, Val8, Ala9, Leu22, Phe31, Tyr33, Phe34, Ile60, Leu67, Val115, and Tyr121, which stabilized the binding of compound 35 in the active site of DHFR. 
Table 3. GLIDE docking results for compounds 35, 27 and methotrexate at the active site of human dihydrofolate reductase.

\begin{tabular}{|c|c|c|c|c|c|}
\hline \multirow{2}{*}{ S. No. } & \multirow{2}{*}{ Ligand Name } & \multirow{2}{*}{ Docking Score } & \multicolumn{3}{|c|}{ Interactions } \\
\hline & & & H-Bonds & $\pi-\pi$ & Hydrophobic \\
\hline 1 & Compound 35 & -6.834 & Glu30, Thr56 & Phe34 & $\begin{array}{c}\text { Ile7, Val8, Ala9, Leu22, Phe31, } \\
\text { Tyr33, Phe34, Ile60, Leu67, } \\
\text { Val115, Tyr121 }\end{array}$ \\
\hline 2 & Compound 27 & -5.211 & Glu30 & Phe34 & $\begin{array}{c}\text { Val8, Ala9, Leu22, Phe34, } \\
\text { Ile60, Leu67, Tyr121 }\end{array}$ \\
\hline 3 & Methotrexate & -11.808 & $\begin{array}{l}\text { Ile7, Glu30, Gln35, } \\
\text { Arg70, Val115 }\end{array}$ & - & $\begin{array}{l}\text { Ile7, Val8, Ala9, Leu22, Phe31, } \\
\text { Tyr33, Phe34, Ile60, Pro61, } \\
\text { Leu67, Val115, Tyr121 }\end{array}$ \\
\hline
\end{tabular}

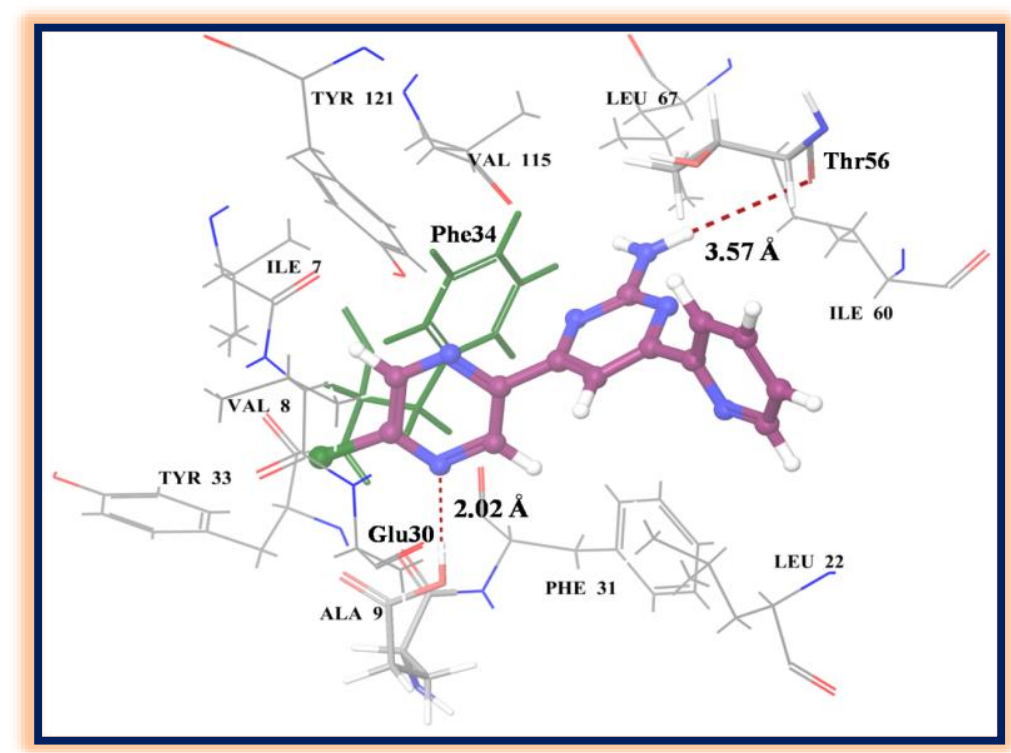

Figure 5. Docking model of compound 35 in the active site of the human dihydrofolate reductase receptor. The red dashed line represents a hydrogen bond. The dark green color residue (Phe34) is involved in the $\pi-\pi$ interaction.

Figure 6 illustrates the superimposition of compound 35 and co-crystal (Methotrexate) at the active site of the human dihydrofolate reductase receptor. Compound $\mathbf{3 5}$ overlapped well with the native ligand Methotrexate at the active site of DHFR and formed key interactions with the active site residues of DHFR.

A bioisosteric 6-membered nitrogenous heterocyclic ring such as $2^{\prime \prime}$-pyridinyl ring containing compound 35 has very good antiproliferative activity and binding affinity compared to compounds of chloropyrazine-tethered pyrimidine hybrids with a simple phenyl ring. This observation can be verified in the case of compound 27 as it has low antiproliferative activity as well as a low docking score and interaction with active site residues compared to compound 35. Figure 7 represents the receptor-ligand interaction diagram (2D view) of compounds 27 at the active site of the human dihydrofolate reductase receptor. 


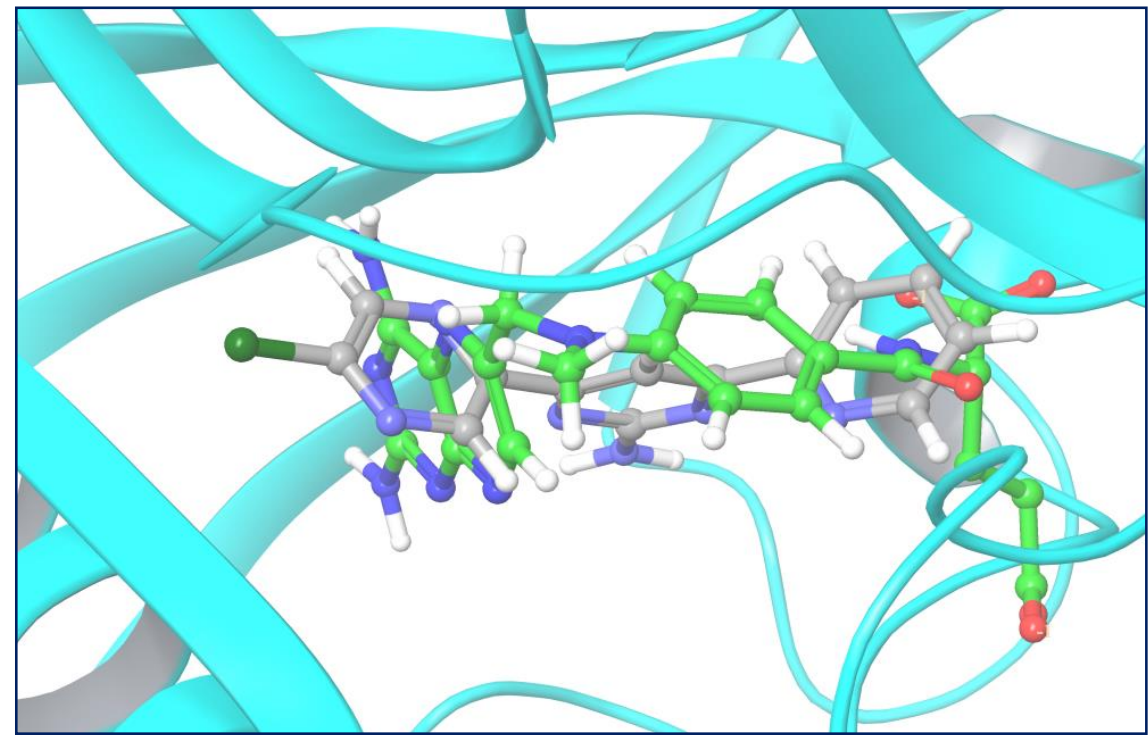

Figure 6. Superimposition of compound 35 (grey) with the co-crystal structure (green) at the active site of the human dihydrofolate reductase receptor (PDB code: 1U72).

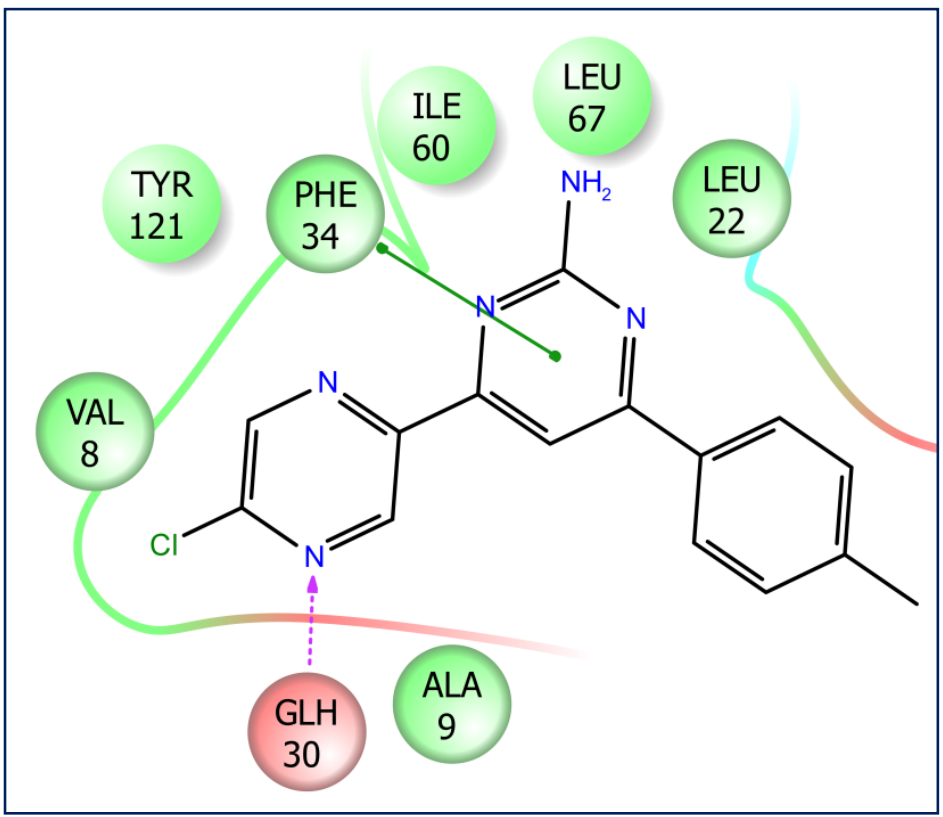

Figure 7. Receptor-ligand interaction diagram (2D view) of compound 27 at the active site of the human dihydrofolate reductase receptor. The maroon-colored arrow and green-colored lines represent hydrogen bonding and $\pi-\pi$ interactions, respectively.

\subsubsection{In Silico Drug-Likeness Studies}

Compound 35, which showed the best potency in the antiproliferative study, was characterized for certain properties using web-based SwissADME software (Table 4). It can be observed that compound 35 passed the Lipinski rule and had high GI absorption and no inhibition effect on CYP2C19. However, it showed an inhibitory effect against CYP2D6. Hence, compound 35 shows good drug-like properties and is considered a potential lead molecule for further in vivo investigation. 
Table 4. Computed properties of compound 35 using SWISSADME.

\begin{tabular}{ccccc}
\hline Compound \# & GI Absorption & $\begin{array}{c}\text { Lipinski } \\
\text { \#Violations }\end{array}$ & $\begin{array}{c}\text { CYP2D6 } \\
\text { Inhibitor }\end{array}$ & $\begin{array}{c}\text { CYP2C19 } \\
\text { Inhibitor }\end{array}$ \\
\hline 35 & High & 0 & Yes & No \\
\hline
\end{tabular}

\section{Materials and Methods}

\subsection{Biological Studies}

\subsubsection{Antibacterial and Antifungal Activities}

The strains used for testing antifungal activity were procured from the Institute of Microbial Technology, Chandigarh, India. Ciprofloxacin and fluconazole were used as standard drugs for antibacterial and antifungal assays, respectively. The organisms used in the study included the bacterial strains Bacillus subtilis (ATCC-60511) and Staphylococcus aureus (ATCC-11632) [Gram-positive], Escherichia coli (ATCC-10536), and Pseudomonas aeruginosa (ATCC-10145) [Gram-negative], as well as fungi: Aspergillus niger (ATCC-6275) and Candida tropicalis (ATCC-1369). The antibacterial activity was executed using nutrient agar whereas the antifungal activity testing was done using potato-dextrose-agar medium. The target compounds with a concentration of $1.024 \mathrm{mg} / \mathrm{mL}$ were prepared by dissolving $2.048 \mathrm{mg} / \mathrm{mL}$ of individual test compounds in different vials separately. The experiments were done three times independently, and the values are reported as the mean of three measurements. The microbes were cultured $\mathrm{n}$ their corresponding medium at $37^{\circ} \mathrm{C}$ and prepared as a suspension comprising 107 cells $/ \mathrm{mL}$ by dilution in nutrient broth medium (sterile). The suspension was utilized as the inoculum. The test tubes used for the experiments were incubated for a period of $18 \mathrm{~h}$ at $37^{\circ} \mathrm{C}$. Analogous testing was carried out without compound, but with other components including the medium, inoculum, and methanol to check there was no influence of methanol for making the dilutions. Initial indication of growth in the test tube was recorded using a spectrophotometer. The MIC values were determined for the target compounds by taking the concentration used in the test tube just before the first indication of growth [59]. The same protocol was done three times to derive the MIC values of the 19 target compounds, and the results reported are the average of three determinations. Due to the structural difference of ciprofloxacin and fluconazole compared to the target hybrids (22-40), the MIC values recorded in $\mu \mathrm{g} / \mathrm{mL}$ were transformed into $\mu \mathrm{M}$.

\subsubsection{Antiproliferative Activity}

The in vitro antiproliferative activity of pyrimidine derivatives (22-40) was screened against DU-145 (prostate cancer cell lines) by the renowned Mosmann's MTT (3-(4,5dimethylthiazol-2-yl)-2,5-diphenyl tetrazolium bromide) assay method [54]. The antiproliferative activity of $\mathbf{2 2 - 4 0}$ was measured to determine their $\mathrm{IC}_{50}$ values by comparison against reference standard Methotrexate (Mtx; positive control). In MTT assay, the principal is based on the fact that in living cells there is a reduction in MTT (soluble, $0.5 \mathrm{mg} / \mathrm{mL}$, $100 \mu \mathrm{L}$ ) due to the enzymatic activity of mitochondrial reductase to blue formazan product.

DU-145 cell lines were cultured at $37^{\circ} \mathrm{C}$ and humidified at $5 \% \mathrm{CO}_{2}$ in Dulbecco's Modified Eagle Medium (DMEM); $0.1 \%$ DMSO was employed to prepare the stock solutions of target compounds (22-40). Later, the required concentrations were obtained by dilution using sterile water. Temporarily, cells were placed on 96-well plates at $100 \mu \mathrm{L}$ total volume, with a density of $1 \times 10^{4}$ cells per well, and allowed to adhere for a duration of $24 \mathrm{~h}$. Further, the medium was substituted with fresh medium containing different dilutions of target compounds and incubated at $37^{\circ} \mathrm{C}$ for an additional $48 \mathrm{~h}$ in DMEM with FBS (Fetal Bovine Serum, 10\%). Then, the medium was substituted by freshly prepared $90 \mu \mathrm{L}$ of DMEM without any FBS. The above wells were incubated for $3-4 \mathrm{~h}$ at $37^{\circ} \mathrm{C}$ after treatment with $10 \mu \mathrm{L}$ MTT reagent ( $5 \mathrm{mg} / \mathrm{mL}$ of stock solution in DMEM without FBS). This resulted in the formation of formazan crystals (blue color). These crystals were solubilized in DMSO $(200 \mu \mathrm{L})$, and the optical density (OD) was assessed using a micro plate 
reader at a wavelength of $570 \mathrm{~nm}$. The assay was done three times as three independent experiments. A similar study was performed in order to check that there was no effect of DMSO on activity. The reproducibility of the results was good, and the standard errors were less than $10 \%$. The results of antiproliferative activity are reported as $\mathrm{IC}_{50}(\mu \mathrm{g} / \mathrm{mL})$ values. Different inhibitor concentrations were added for the calculation of the $\mathrm{IC}_{50}$ values.

\subsection{In Silico Studies}

\subsubsection{Molecular Docking}

The crystal structures of DHFR and the methotrexate complex were obtained from the Protein Data Bank (PDB ID: 1U72). The protein preparation tool was used for the preparation of the DHFR. The grid was generated by selecting the active site where the co-crystal was located, with a grid box of $10 \times 10 \times 10 \AA$ (Schrödinger 2014-3). With the use of the 2D sketcher, the potent compound 35 was sketched and energy minimized, and ligand preparation was performed for the generation of different conformers (Schrödinger 2014-3). The various conformers obtained were subjected to molecular docking with XP Glide (Schrödinger 2014-3). The poses generated were assessed, and the best one was reported.

\subsubsection{In Silico Drug Likeness Prediction}

SwissADME, a web tool, was utilized to evaluate the properties of the most potent compound 35 using in-silico parameters such as GI absorption, Lipinski rule of five, and CYP2C19 and CYP2D6 inhibition, in order to meet the requirements of the drug-likeness. (http:/ / www.swissadme.ch/ (accessed on 17 September 2021)) [60].

\section{Conclusions}

Here, we report the antimicrobial (antibacterial and antifungal) and antiproliferative activities of 19 chloropyrazine-tethered pyrimidine hybrids (22-40) synthesized previously by replacing the 1,5-benzothiazepine scaffold of chloropyrazine-linked 1,5-benzothiazepine derivatives. The tested analogues (22-40) showed more antiproliferative activity and less antimicrobial activity than the corresponding chloropyrazine-linked 1,5-benzothiazepine derivatives. The results indicated that the electron-withdrawing atoms/groups on the phenyl ring of the chloropyrazine-tethered pyrimidine hybrids are vital for improving the antimicrobial, whereas the bioisosteric heteroaryl scaffold $2^{\prime \prime}$-pyridinyl substitutions are vital for antiproliferative activity. Compound 31, containing a $2^{\prime \prime}, 4^{\prime \prime}$-dichlorophenyl ring, showed the most potent antibacterial and antifungal activities with an MIC value of 45.37 $\mu \mathrm{M}$, while compounds 25 and 30, containing $4^{\prime \prime}$-nitrophenyl and $2^{\prime \prime}, 4^{\prime \prime}$-difluorophenyl moieties, had MIC values of $48.67 \mu \mathrm{M}$ and $50.04 \mu \mathrm{M}$, respectively. Compound 35, containing a $2^{\prime \prime}$-pyridinyl ring, showed the most potent $\mathrm{IC}_{50}$ value of $5 \pm 1 \mu \mathrm{g} / \mathrm{mL}$ against DU-145. All compounds can be considered safe as they had less selectivity to LO2 normal human liver cells compared to the cancerous cells. Molecular docking results for compound 35 showed major binding interactions at the binding site, correlating with the in vitro antiproliferative activity as well as the SwissADME results of $\mathbf{3 5}$ for drug-likeness, suggesting the usefulness of computational studies in the development of new drug-like candidates. The potential lead compounds identified through this work will be useful in the further design and optimization of drug candidates against antimicrobial activities, and compound $\mathbf{3 5}$ is a potential lead compound for the development of new anticancer agents.

Author Contributions: Conceptualization, R.R.B. and A.B.S.; methodology, A.B.S.; software, R.R.B.; validation, R.R.B. and A.B.S.; formal analysis, R.R.B. and A.B.S.; investigation, A.B.S.; resources, R.R.B. and A.B.S.; data curation, A.B.S.; writing-original draft preparation, R.R.B. and A.B.S.; writing-review and editing, R.R.B. and A.B.S.; visualization, A.B.S.; supervision, A.B.S.; project administration, R.R.B. and A.B.S.; funding acquisition, R.R.B. and A.B.S. All authors have read and agreed to the published version of the manuscript. 
Funding: This research received no external funding. RRB is thankful to the Deanship of Graduate Studies and Research (DGSR), Ajman University, for providing partial funding for the article processing charges.

Institutional Review Board Statement: Not applicable.

Informed Consent Statement: Not applicable.

Data Availability Statement: Not applicable.

Acknowledgments: Richie R. Bhandare would like to thank the Dean's Office of the College of Pharmacy and Health Sciences, Ajman University, United Arab Emirates, and Afzal B. Shaik extends his thanks to Vignan Pharmacy College, Vadlamudi, Andhra Pradesh, India. Richie R Bhandare would like to thank the Deanship of Graduate Studies and Research, Ajman University for providing partial funding of article processing charges.

Conflicts of Interest: The authors declare no conflict of interest.

Sample Availability: Samples of the compounds were utilized for spectral characterization and biological evaluation; hence, the samples are currently unavailable from the authors.

\section{References}

1. Gomtsyan, A. Heterocycles in drugs and drug discovery. Chem. Heterocycl. Compd. 2012, 48, 7-10. [CrossRef]

2. Burch, J.D.; Farand, J.; Colucci, J.; Sturino, C.; Ducharme, Y.; Friesen, R.W.; Lévesque, J.F.; Gagné, S.; Wrona, M.; Therien, A.G.; et al. Naphthalene/quinoline amides and sulfonylureas as potent and selective antagonists of the EP4 receptor. Bioorg. Med. Chem. Lett. 2011, 21, 1041-1046. [CrossRef]

3. Viegas-Junior, C.; Danuello, A.; da Silva Bolzani, V.; Barreiro, E.J.; Fraga, C.A.M. Molecular hybridization: A useful tool in the design of new drug prototypes. Curr. Med. Chem. 2007, 14, 1829-1852. [CrossRef]

4. FDA. Novel Drug Approvals for 2021. Available online: https://www.fda.gov/drugs/new-drugs-fda-cders-new-molecularentities-and-new-therapeutic-biological-products/novel-drug-approvals-2021 (accessed on 19 March 2021).

5. Miniyar, P.B.; Murumkar, P.R.; Patil, P.S.; Barmade, M.A.; Bothara, K.G. Unequivocal role of pyrazine ring in medicinally important compounds: A review. Mini Rev. Med. Chem. 2013, 13, 1607-1625. [CrossRef]

6. Semelkova, L.; Konecna, K.; Paterova, P.; Kubicek, V.; Kunes, J.; Novakova, L.; Marek, J.; Naesens, L.; Pesko, M.; Kralova, K.; et al. Synthesis and Biological Evaluation of N-Alkyl-3-(alkylamino)-pyrazine-2-carboxamides. Molecules 2015, 20, 8687-8711. [CrossRef]

7. Panda, S.S.; Detistov, O.S.; Girgis, A.S.; Mohapatra, P.P.; Samir, A.; Katritzky, A.R. Synthesis and molecular modeling of antimicrobial active fluoroquinolone-pyrazine conjugates with amino acid linkers. Bioorg. Med. Chem. Lett. 2016, 26, $2198-2205$. [CrossRef] [PubMed]

8. Kucerova-Chlupacova, M.; Vyskovska-Tyllova, V.; Richterova-Finkova, L.; Kunes, J.; Buchta, V.; Vejsova, M.; Paterova, P.; Semelkova, L.; Jandourek, O.; Opletalova, V. Novel halogenated pyrazine-based chalcones as potential antimicrobial drugs. Molecules 2016, 21, 1421. [CrossRef]

9. Semelková, L.; Jand'ourek, O.; Konečná, K.; Paterová, P.; Navrátilová, L.; Trejtnar, F.; Kubíček, V.; Kuneš, J.; Doležal, M.; Zitko, J. 3Substituted N-Benzylpyrazine-2-carboxamide Derivatives: Synthesis, Antimycobacterial and Antibacterial Evaluation. Molecules 2017, 22, 495. [CrossRef] [PubMed]

10. Bassin, J.P.; Botha, M.J.; Garikipati, R.; Goyal, M.; Martin, L.; Shah, A. Synthesis and Antibacterial Activity of Benzo [4,5] isothiazolo [2, 3-a] pyrazine-6, 6-dioxide Derivatives. Molecules 2017, 22, 1889. [CrossRef]

11. Mangrolia, U.; Osborne, W.J. Staphylococcus xylosus VITURAJ10: Pyrrolo[1,2 $\alpha$ ]pyrazine-1,4-dione,hexahydro-3-(2-methylpropyl) (PPDHMP) producing, potential probiotic strain with antibacterial and anticancer activity. Microb. Pathog. 2020, 147, 104259. [CrossRef]

12. Kratky, M.; Vinsova, J.; Buchta, V. In vitro antibacterial and antifungal activity of salicylanilide pyrazine-2-carboxylates. Med. Chem. 2012, 8, 732-741. [CrossRef] [PubMed]

13. Kucerova-Chlupacova, M.; Kunes, J.; Buchta, V.; Vejsova, M.; Opletalova, V. Novel pyrazine analogs of chalcones: Synthesis and evaluation of their antifungal and antimycobacterial activity. Molecules 2015, 20, 1104-1117. [CrossRef]

14. Zaki, R.M.; Kamal, E.D.; Radwan, S.M.; Abd ul-Malik, M.A. A convenient synthesis, reactions and biological activities of some novel thieno [3, 2-e] pyrazolo [3, 4-b] pyrazine compounds as anti-microbial and anti-inflammatory agents. Curr. Org. Synth. 2018, 15, 863-871. [CrossRef]

15. Chylewska, A.; Dąbrowska, A.M.; Ramotowska, S.; Maciejewska, N.; Olszewski, M.; Bagiński, M.; Makowski, M. Photosensitive and $\mathrm{pH}$-dependent activity of pyrazine-functionalized carbazole derivative as promising antifungal and imaging agent. Sci. Rep. 2020, 10, 1-13. [CrossRef]

16. Goel, R.; Luxami, V.; Paul, K. Synthesis, in vitro anticancer activity and SAR studies of arylated imidazo[1,2-a]pyrazine-coumarin hybrids. RSC Adv. 2015, 5, 37887-37895. [CrossRef] 
17. El-Kashef, H.; El-Emary, T.; Verhaeghe, P.; Vanelle, P.; Samy, M. Anticancer and anti-inflammatory activities of some new pyrazolo [3, 4-b] pyrazines. Molecules 2018, 23, 2657. [CrossRef] [PubMed]

18. Wang, S.; Yuan, X.; Qian, H.; Li, N.; Wang, J. Design, Synthesis, and Biological Evaluation of Two Series of Novel A-Ring Fused Steroidal Pyrazines as Potential Anticancer Agents. Int. J. Mol. Sci. 2020, 21, 1665. [CrossRef]

19. Seo, Y.; Lee, J.H.; Park, S.H.; Namkung, W.; Kim, I. Expansion of chemical space based on a pyrrolo[1,2-a]pyrazine core: Synthesis and its anticancer activity in prostate cancer and breast cancer cells. Eur. J. Med. Chem. 2020, 188, 111988. [CrossRef] [PubMed]

20. Raveesha, R.; Kumar, M.G.D.; Prasad, S.B.B. Synthesis of 3-Trifluoromethyl-5, 6-dihydro-[1,2,4]triazolo Pyrazine Derivatives and Their Anti-Cancer Studies. Molbank 2020, 4, M1173. [CrossRef]

21. Zaki, R.M.; Abdul-Malik, M.A.; Saber, S.H.; Radwan, S.M.; El-Dean, A.M.K. A convenient synthesis, reactions and biological evaluation of novel pyrazolo [3,4-b] selenolo [3,2-e] pyrazine heterocycles as potential anticancer and antimicrobial agents. Med. Chem. Res. 2020, 29, 2130-2145. [CrossRef]

22. Packiaraj, S.; Kousalya, L.; Pushpaveni, A.; Poornima, S.; Puschmann, H.; Govindarajan, S. Structural and antioxidant properties of guanylhydrazinium pyrazine-2-carboxylate. J. Mater. Sci. Mater. Electron. 2021, 32, 1-15. [CrossRef]

23. Kucerova-Chlupacova, M.; Dosedel, M.; Kunes, J.; Soltesova-Prnova, M.; Majekova, M.; Stefek, M. Chalcones and their pyrazine analogs: Synthesis, inhibition of aldose reductase, antioxidant activity, and molecular docking study. Monatsh. Chem. 2018, 149, 921-929. [CrossRef]

24. Stepanić, V.; Matijašić, M.; Horvat, T.; Verbanac, D.; Kučerová-Chlupáčová, M.; Saso, L.; Žarković, N. Antioxidant Activities of Alkyl Substituted Pyrazine Derivatives of Chalcones-In Vitro and In Silico Study. Antioxidants 2019, 8, 90. [CrossRef] [PubMed]

25. Moghaddas, S.A.; Hossaini, Z.; Zareyee, D. Green synthesis and investigation of antioxidant ability new pyrazines containing pyrrolo [2, 1-a] isoquinolines derivatives. J. Heterocycl. Chem. 2020, 57, 3856-3867. [CrossRef]

26. Reddyrajula, R.; Dalimba, U. The bioisosteric modification of pyrazinamide derivatives led to potent antitubercular agents: Synthesis via click approach and molecular docking of pyrazine-1, 2, 3-triazoles. Bioorg. Med. Chem. Lett. 2020, $30,126846$. [CrossRef] [PubMed]

27. Wati, F.A.; Adyarini, P.U.; Fatmawati, S.; Santoso, M. Synthesis of pyrazinamide analogues and their antitubercular bioactivity. Med. Chem. Res. 2020, 29, 2157-2163. [CrossRef]

28. Das, R.; Mehta, D.K. Evaluation and Docking Study of Pyrazine Containing 1, 3, 4-Oxadiazoles Clubbed with Substituted Azetidin-2-one: A New Class of Potential Antimicrobial and Antitubercular. Drug Res. 2021, 71, 26-35. [CrossRef]

29. Mallikarjunaswamy, C.; Mallesha, L.; Bhadregowda, D.G.; Pinto, O. Studies on synthesis of pyrimidine derivatives and their antimicrobial activity. Arab. J. Chem. 2017, 10, S484-S490. [CrossRef]

30. Tiwari, S.V.; Seijas, J.A.; Vazquez-Tato, M.P.; Sarkate, A.P.; Karnik, K.S.; Nikalje, A.P.G. Ionic liquid-promoted synthesis of novel chromone-pyrimidine coupled derivatives, antimicrobial analysis, enzyme assay, docking study and toxicity study. Molecules 2018, 23, 440. [CrossRef]

31. Fouda, A.M.; Abbas, H.A.S.; Ahmed, E.H.; Shati, A.A.; Alfaifi, M.Y.; Elbehairi, S.E.I. Synthesis, in vitro antimicrobial and cytotoxic activities of some new pyrazolo[1,5-a]pyrimidine derivatives. Molecules 2019, 24, 1080. [CrossRef]

32. Sui, Y.F.; Li, D.; Wang, J.; Bheemanaboina, R.R.Y.; Ansari, M.F.; Gan, L.L.; Zhou, C.H. Design and biological evaluation of a novel type of potential multi-targeting antimicrobial sulfanilamide hybrids in combination of pyrimidine and azoles. Bioorg. Med. Chem. Lett. 2020, 30, 126982. [CrossRef]

33. Naglah, A.M.; Askar, A.A.; Hassan, A.S.; Khatab, T.K.; Al-Omar, M.A.; Bhat, M.A. Biological evaluation and molecular docking with in silico physicochemical, pharmacokinetic and toxicity prediction of pyrazolo[1,5-a]pyrimidines. Molecules 2020, $25,1431$. [CrossRef]

34. Gomha, S.M.; Zaki, Y.H.; Abdelhamid, A.O. Utility of 3-Acetyl-6-bromo-2H-chromen-2-one for the synthesis of new heterocycles as potential antiproliferative agents. Molecules 2015, 20, 21826-21839. [CrossRef] [PubMed]

35. Verbitskiy, E.V.; Cheprakova, E.M.; Slepukhin, P.A.; Kravchenko, M.A.; Skornyakov, S.N.; Rusinov, G.L.; Chupakhin, O.N.; Charushin, V.N. Synthesis, and structure-activity relationship for C (4) and/or C (5) thienyl substituted pyrimidines, as a new family of antimycobacterial compounds. Eur. J. Med. Chem. 2015, 97, 225-234. [CrossRef] [PubMed]

36. Kaur, H.; Singh, L.; Chibale, K.; Singh, K. Structure elaboration of isoniazid: Synthesis, in silico molecular docking and antimycobacterial activity of isoniazid-pyrimidine conjugates. Mol. Divers. 2020, 24, 949-955. [CrossRef]

37. Santoso, K.T.; Brett, M.W.; Cheung, C.Y.; Cook, G.M.; Stocker, B.L.; Timmer, M.S. Synthesis of FunctionalisedChromonylpyrimidines and Their Potential as Antimycobacterial Agents. ChemistrySelect 2020, 5, 4347-4355. [CrossRef]

38. Dar'in, D.; Rogacheva, E.; Kraeva, L.; Levin, O.; Manicheva, O.; Dogonadze, M.; Vinogradova, T.; Bakulina, O.; Krasavin, M. Mutually Isomeric 2-and 4-(3-nitro-1, 2, 4-triazol-1-yl) pyrimidines Inspired by an Antimycobacterial Screening Hit: Synthesis and Biological Activity against the ESKAPE Panel of Pathogens. Antibiotics 2020, 9, 666. [CrossRef]

39. Kostova, I.; Atanasov, P.Y. Antioxidant Properties of Pyrimidine and Uracil Derivatives. Curr. Org. Chem. 2017, 21, 2096-2108. [CrossRef]

40. Emam, D.R.; Alhajoj, A.M.; Elattar, K.M.; Kheder, N.A.; Fadda, A.A. Synthesis and evaluation of curcuminoid analogues as antioxidant and antibacterial agents. Molecules 2017, 22, 971. [CrossRef]

41. Naidu Kalla, R.M.; Karunakaran, R.S.; Balaji, M.; Kim, I. Catalyst-Free Synthesis of Xanthene and Pyrimidine-Fused Heterocyclic Derivatives at Water-Ethanol Medium and Their Antioxidant Properties. ChemistrySelect 2019, 4, 644-649. [CrossRef] 
42. Abdelgawad, M.A.; Bakr, R.B.; Ahmad, W.; Al-Sanea, M.M.; Elshemy, H.A. New pyrimidine-benzoxazole/benzimidazole hybrids: Synthesis, antioxidant, cytotoxic activity, in vitro cyclooxygenase and phospholipase A2-V inhibition. Bioorg. Chem. 2019, 92, 103218. [CrossRef]

43. Reddy, O.S.; Suryanarayana, C.V.; Narayana, K.J.P.; Anuradha, V.; Babu, B.H. Synthesis and cytotoxic evaluation for some new 2, 5-disubstituted pyrimidine derivatives for anticancer activity. Med. Chem. Res. 2015, 24, 777-1788. [CrossRef]

44. Shi, J.B.; Tang, W.J.; Li, R.; Liu, X.H. Novel pyrazole-5-carboxamide and pyrazole-pyrimidine derivatives: Synthesis and anticancer activity. Eur. J. Med. Chem. 2015, 90, 889-896. [CrossRef]

45. Abdallah, M.A.; Gomha, S.M.; Abbas, I.M.; Kazem, M.S.; Alterary, S.S.; Mabkhot, Y.N. An efficient synthesis of novel pyrazolebased heterocycles as potential antitumor agents. Appl. Sci. 2017, 7, 785. [CrossRef]

46. Murahari, M.; Prakash, K.V.; Peters, G.J.; Mayur, Y.C. Acridone-pyrimidine hybrids-design, synthesis, cytotoxicity studies in resistant and sensitive cancer cells and molecular docking studies. Eur. J. Med. Chem. 2017, 139, 961-981. [CrossRef]

47. Abbass, E.M.; Khalil, A.K.; El-Naggar, A.M. Eco-friendly synthesis of novel pyrimidine derivatives as potential anticancer agents. J. Heterocycl. Chem. 2020, 57, 1154-1164. [CrossRef]

48. Radwan, M.A.; Alminderej, F.M.; Awad, H.M. One-pot multicomponent synthesis and cytotoxic evaluation of novel 7-substituted5-(1H-indol-3-yl)tetrazolo[1,5-a]pyrimidine-6-carbonitrile. Molecules 2020, 25, 255. [CrossRef]

49. Madia, V.N.; Nicolai, A.; Messore, A.; De Leo, A.; Ialongo, D.; Tudino, V.; Saccoliti, F.; De Vita, D.; Scipione, L.; Artico, M.; et al. Design, Synthesis and Biological Evaluation of New Pyrimidine Derivatives as Anticancer Agents. Molecules 2021, 26,771 [CrossRef]

50. Bai, S.; Liu, S.; Zhu, Y.; Wu, Q. Asymmetric synthesis and antiviral activity of novel chiral amino-pyrimidine derivatives. Tetrahedron. Lett. 2018, 59, 3179-3183. [CrossRef]

51. Wu, L.; Liu, Y.; Li, Y. Synthesis of spirooxindole-O-naphthoquinone-tetrazolo[1,5-a]pyrimidine hybrids as potential anticancer agents. Molecules 2018, 23, 2330. [CrossRef]

52. Kumar, S.; Deep, A.; Narasimhan, B. A review on synthesis, anticancer and antiviral potentials of pyrimidine derivatives. Curr. Bioact. Compd. 2019, 15, 289-303. [CrossRef]

53. Yates, M.K.; Chatterjee, P.; Flint, M.; Arefeayne, Y.; Makuc, D.; Plavec, J.; Spiropoulou, C.F.; Seley-Radtke, K.L. Probing the effects of pyrimidine functional group switches on acyclic fleximer analogues for antiviral activity. Molecules 2019, 24, 3184. [CrossRef]

54. Shaik, A.B.; Bhandare, R.R.; Nissankararao, S.; Lokesh, B.V.S.; Shahanaaz, S.; Rahman, M.M. Synthesis, and biological screening of chloropyrazine conjugated benzothiazepine derivatives as potential antimicrobial, antitubercular and cytotoxic agents. Arab. J. Chem. 2021, 14, 102915. [CrossRef]

55. Vegesna, S.; Yejella, R.P.; Shaik, A.B. Synthesis and antitubercular evaluation of some novel pyrimidine derivatives. Int. J. Res. Pharm. Chem. 2017, 7, 181-186.

56. Raimondi, M.V.; Randazzo, O.; La Franca, M.; Barone, G.; Vignoni, E.; Rossi, D.; Collina, S. DHFR Inhibitors: Reading the Past for Discovering Novel Anticancer Agents. Molecules 2019, 24, 1140. [CrossRef] [PubMed]

57. Schrödinger Suite 2014-3; Schrödinger, LLC.: New York, NY, USA, 2014.

58. Cody, V.; Luft, J.R.; Pangborn, W. Understanding the role of Leu22 variants in methotrexate resistance: Comparison of wild-type and Leu22Arg variant mouse and human dihydrofolate reductase ternary crystal complexes with methotrexate and NADPH. Acta Crystallogr. D Biol. Crystallogr. 2005, 61, 147-155. [CrossRef] [PubMed]

59. Vegesna, S.; Yejella, R.P.; Shaik, A.B. Antimicrobial evaluation of some novel pyrazine based chalcones. Int. J. Adv. Pharm. Sci. 2017, 8, 11-18.

60. Swiss Institute of Bioinformatics. SwissADME. Available online: http:/ / www.swissadme.ch/ (accessed on 17 September 2021). 